\title{
pl 6 Overexpression: A Potential Early Indicator of Transformation in Ovarian Carcinoma
}

\author{
K. Shigemasa, MD, C. Hu, MD, C. M. West, J. Clarke, G. P. Parham, MD, \\ T. H. Parmley, MD, S. Korourian, PhD, V. V. Baker, MD, \\ and T. J. O'Brien, $\mathrm{PhD}$
}

\begin{abstract}
OBJECTIVE: The recently cloned gene $p 16$ (MST1) has been identified as a putative tumor suppressor gene that binds to CDK4 and CDK6 (cyclin-dependent kinases), preventing their interaction with cyclin $D 1$ and thereby preventing cell cycle progression at the G1 stage. In addition, the $p 16$ gene has been shown to have a high frequency of mutation in some tumor cell lines; however, it has also been shown that a much lower frequency of mutation occurs in primary tumors. This study investigated the $m R N A$ expression level and mutation status of the 16 gene in ovarian tumors.

METHODS: We performed quantitative polymerase chain reaction and direct $C D N A$ sequencing analysis. To confirm the $p 16$ protein level in ovarian tumors, Western blotting and immunohistochemical staining were performed. Expression levels of $m R N A$ for the $p 16$ gene relative to the $\beta$-tubulin gene were examined in 32 ovarian tumors (24 carcinomas, six low malignant potential tumors, and two benign tumors) and six normal ovaries.

RESULts: The $m R N A$ expression level of $p 16$ was significantly elevated in 28 ovarian tumors (22 carcinomas, five low malignant potential tumors, and one benign tumor) compared with that of normal ovaries. Westem blotting analysis and immunohistochemical staining confirmed elevated $p 16$ protein levels in ovarian tumor samples. Among 32 ovarian tumors, $c D N A$ sequencing of the $p 16$ gene showed no $p 16$ mutation resulting in a coding error, although one silent mutation and three polymorphisms were found. Conclusions: Although $p 16$ is seldom mutated in ovarian tumors, the overexpression of $p 16$ in most ovarian tumer cases indicates a dysfunction in the regulatory complex for $G 1$ arrest. Therefore, overexpression of p16 may be an important early event in the neoplastic transformation of the ovarian epithelium. ( $J$ Soc Gynecol Invest 1997;4:95-102. Copyright (C) 1997 by the Society for Cynecologic Investigation.)
\end{abstract}

KEY WORDs: p16, mRNA expression, mutation status, ovarian cancer.

$\mathrm{T}$ To date, ovarian cancer remains the number one killer of women with gynecologic cancer. Approximately $75 \%$ of women are diagnosed with high-stage (III and IV) disease. During the past 20 years, neither diagnosis nor 5 -year survival have improved greatly. It remains a challenge to develop new markers to detect early disease and to characterize biologic modifiers that will down-regulate metastatic disease.

In light of the potential of gene therapy, it seems appropriate to establish a data base to catalog the genetic alterations of either oncogenes or suppressor genes that might contribute to

From the Departments of Obstetrics and Gynecology, Biochernistry and Molecular Biology, and Pathology. University of Arkansas for Medical Sciences, Little Rock, Arkansas: and the Division of Gynecologic Oncology, University of Michigan Medical Center, Ann Arbor, Michigan.

The authors acknowledge the participation of the following divisions of the Cooperative Human Tissue Network (CHTN) in providing tumor tissues: Western Division, Case Western Reserve University (Cleveland, OH); Midwestern Division, Ohio Stat University (Columbus, OH); Eastem Division. NDRI (Philadelphia, PA); Pediatric Division. Children's Hospital (Columbus, $\mathrm{OH}$ ); and Southern Division, Lniversity of Alabama at Birmingham (Birmingham. $\mathrm{AL}$ )

Address correspondence and repnint requests to Timothy J. O'Brien, PhD, Director. Biomedical Biotechnology Center, 4301 W. Markham. Slot 718. Little Rock, AK 72205

Copyright 1997 by the Society for Gynecologic Investigation.

Published by Elsevier Science Inc. the phenotypic changes necessary to down-regulate tumor cells. We have initiated a tumor data base including patients with all grades of ovarian cancer as well as normal ovaries. The data base is intended to document the genes associated with signal transduction, cell-cycle, or cell-surface control mechanisms that may be insulted (mutated) or whose expression may be modified as a result of the transformation process. Such information may aid the selection of appropriate biologic modifiers for gene therapy. The data base is presently being developed by examining the sequence and expression status of known oncogenes and suppressor genes by isolating mRNA from fresh frozen specimens and using polymerase chain reaction (PCR) to examine the products derived from cDNA synthesized from mRNA. We have looked at the expression of p55 and p21 and sequenced p 53 to determine mutations. Our overall findings corroborate other investigations in that approximately $50 \%$ of high-stage tumors have $\mathrm{p} 53$ mutations and underexpress the p21 gene. We have also begun to evaluate cell-cycle control genes because of their obvious potential in contributing to the growth of tumors that may or may not 
have a p53 mutation. In recent years, many of the genes involved in cell-cycle control have been identified and cloned, and the products of these genes have been documented. ${ }^{1-4}$ Cyclin-dependent kinases, along with their cyclin-specific counterparts, are responsible primarily for driving the cell cycle past the G1 stage through phosphorylation of the Rb protein. ${ }^{5}$ Once retinoblastoma protein is phosphorylated, it releases the transcription factor E2F, which is required for progression from $G^{1}$ to the $S$ phase of the cell cycle. ${ }^{6}$ There also exists a series of suppressors of cell division, which includes p21, p16, p15, and p107. ${ }^{2-4}$ Among these suppressors, p16 has been documented as frequently mutated in many cell lines, presumably producing a dysfunctional p16 protein product, which cannot inhibit the CDK4 and CDK6 kinase reaction. ${ }^{7-9}$ More recently, in a series of primary tumors, it has been established that relatively few specimens had documentable mutations in p16. ${ }^{10-12}$ In this report, we examine the expression and mutational status of the p16 gene in ovarian carcinoma with regard to both type and stage of disease.

\section{MATERIALS AND METHODS}

\section{Tissue Samples}

Ovarian epithelial tumor samples were obtained from 32 patients. The series consisted of cwo cases of benign cystadenomas, six cases of cystadenomas of low malignant potential, and 24 cases of cystadenocarcinomas. The clinical stage of all tumors was classified using the International Federation of Gynecology and Obstetrics criteria. Normal ovaries were obtained from six patients who underwent surgery for benign gynecologic disease. The tissue samples were obtained immediately after the surgical procedure and were frozen in liquid nitrogen and stored at $-80^{\circ} \mathrm{C}$

\section{mRNA Isolation and cDNA Synthesis}

Extraction of mRNA from the tissue samples and complementary DNA synthesis were performed according to the methods we described previously. ${ }^{13}$ Briefly, mRNA was isolated by using a RiboSep mRNA isolation kit (Becton Dickinson Labware). In this procedure, poly $A+m R N A$ was isolated directly from the tissue lysate using the affinity chromatography medium Oligo (dT) Cellulose. The amount of mRNA recovered was quantified by ultraviolet spectrophotometry. The cDNA was synthesized with $5.0 \mu \mathrm{g}$ of mRNA by random hexamer priming using the 1 st strand cDNA synthesis kit (Clontech). The efficiency of cDNA synthesis was estimated by using a glyceraldehyde-3-phosphate dehydrogenasepositive control amplifier (Clontech).

\section{Quantitative PCR and Primer Sequences}

Quantitative PCR was performed according to the method of Noonan et $\mathrm{al}^{14}$ with some modifications. The primer sequences used in this study were designed according to the cDNA sequences described by Serrano et al, ${ }^{7}$ Hall et al, ${ }^{13}$ and Okamoto et al. ${ }^{12}$ For Quantitative PCR: p16 sense primer, 5-CCCCACTACCGTAAATG-3; p16 antisense primer, 5-GAGCTTTGGTTCTGCCA-3; $\beta$-tubulin sense primer, 5-TGCATTGACAACGAGGC-3; and $\beta$-tubulin antisense primer, 5-CTGTCTTGACATTGTTG-3. For cDNA Sequencing: p16 1A sense primer, 5-CGCACCGAATAGTTACG-3; p16 1B antisense primer, 5-CCAGCGTGTCCAGGAAG-3; 162 A sense primer, 5-CTTCCTGGACACGCTGG-3; and p16 2B antisense primer, 5-CTGTAGGACCTTCGGTG-3. Pairs of the primers were designed to include at least one intron-exon splice site in the corresponding genomic sequence to eliminate amplification from genomic DNA. The PCR reaction mixture consisted of $\mathrm{CDNA}$ derived from $50 \mathrm{ng}$ of mRNA, $5 \mathrm{pmol}$ of sense and antisense primers for both the target gene and the $\beta$-tubulin gene, 200 $\mu \mathrm{mol}$ of dNTPs, $5 \mu \mathrm{Ci}$ of $\left[\alpha-{ }^{32} \mathrm{P}\right] \mathrm{dCTP}$, and $0.25 \mathrm{U}$ of Taq DNA polymerase with reaction buffer (Promega) in a final volume of $25 \mu \mathrm{L}$. The target sequences were amplified in parallel with the $\beta$-tubulin gene as an internal control. Thirty cycles of PCR were carried out in a thermal cycler (PerkinElmer Cetus). Each cycle of PCR included 30 seconds of denaturation at $95^{\circ} \mathrm{C}, 1$ minute of primer annealing at $62^{\circ} \mathrm{C}$, and 1 minute of extension at $72^{\circ} \mathrm{C}$

The products were separated on a $2 \%$ agarose gel, and the radioactivity of each band was determined using a Phospho Imager (Molecular Dynamics).

\section{Direct cDNA Sequencing}

To prepare the template DNA for the sequencing reaction, we performed PCR with the amplification primers as described earlier. The p16 cDNA was sequenced from codon 40 to the terminal amino acid, covering from the middle of exon 1 through the end of exon 3. Amplified cDNA samples were purified using Wizard PCR Preps DNA purification system (Promega). The sequencing reaction was carried out using a PRISM Ready Reaction DyeDeoxy Terminator Cycle Sequencing Kit (Applied Biosystems). To remove excess DyeDeoxy, spin columns were used (Princeton Separation). An applied Biosystems Model 373A DNA Sequencing System was used for direct cDNA sequence determination.

\section{Western Blotting}

A protein lysate was prepared from $0.5 \mathrm{~g}$ of frozen tissue pulverized under liquid nitrogen. We added to the tissue $0.5 \mathrm{~mL}$ of $2 \times$ sodium dodecylsulfate (SDS) sample buffer $(62.5$ $\mathrm{mmol} / \mathrm{L}$ Tris- $\mathrm{HCl}, \mathrm{pH} 6.8,4 \%$ SDS, $0.01 \%$ glycerol, $0.05 \%$ $2-\beta$-mercaptoethanol, and $0.05 \%$ bromophenol blue) containing $10 \mu \mathrm{mol} / \mathrm{L}$ phenylarsine oxide, $2 \mathrm{mmol} / \mathrm{L}$ sodium orchovanadate, $1.3 \mathrm{mmol} / \mathrm{L}$ ethyleneglycol-bis- $(\beta$-aminoethylether)-N, N, $\mathrm{N}^{\prime}, \mathrm{N}^{\prime}$-tetra-acetic acid, and $100 \mu \mathrm{mol} / \mathrm{L}$ trifluoperazine. The sample was placed in a boiling water bath for 5 minutes and thereafter was centrifuged at $10,000 \mathrm{rpm}$ for 10 minutes. The supernatant at $50 \mu \mathrm{g}$ protein/lane was used for electrophoresis on a $13 \%$ SDS polyacrylamide gel.

Proteins were transferred electrophoreticaily to PVDF membranes (Bio-Rad) for 20 hours at $30 \mathrm{~V}$. Membranes were 
blocked with nonfat milk, incubated with $4 \mu \mathrm{g} / \mathrm{mL}$ purified anti-human $\mathrm{p} 16^{\mathrm{INK} 4}$ monoclonal antibody (Pharmingen) for 3 hours, incubated with goat anti-mouse $\operatorname{IgG}$ horseradish peroxidase complex (Bio-Rad), and developed with horseradish peroxidase color development reagent (Bio-Rad).

\section{Immunohistochemistry}

Immunohistochemical staining was performed using a Vectastain Elite $\mathrm{ABC}$ kit (Vector). Formalin-fixed and paraffinembedded specimens were routinely deparaffinized and incubated in methanol with $0.3 \% \mathrm{H}_{2} \mathrm{O}_{2}$ for 30 minutes at room temperature to block endogenous peroxidase activity. After treatment, the samples were incubated with $10 \mu \mathrm{g} / \mathrm{mL}$ purified anti-human p16 $6^{\mathrm{INK} 4}$ monoclonal antibody (Pharmagen) for 18 hours at $4^{\circ} \mathrm{C}$ in a moisture chamber, incubated with biotinylated anti-mouse $\mathrm{lgG}$ (Vector) for 30 minutes at room temperature, and thereafter incubated with $\mathrm{ABC}$ reagent (Vector) for 30 minutes at room temperature. The final products were visualized by using diaminobenzidine $(0.2 \mathrm{mg} / \mathrm{mL})$ in the presence of $0.003 \% \mathrm{H}_{2} \mathrm{O}_{2}$, and sections were counterstained with $1 \%$ methyl green before clearing and mounting. Negative controls were performed by substituting nonimmune serum for the primary antibody.

\section{RESULTS}

\section{Quantitative PCR of p16 Expression}

To determine the number of PCR cycles appropriate for quantification, we monitored PCR amplification from cycle 15 through cycle 35 every five cycles. Linearity of the $\beta$-tubulin gene and p16 gene PCR products was consistent over 30 cycles (Figure 1), and therefore 30 cycles of PCR was used routinely for expression of the pl6 gene.

To compare the expression of $\mathrm{p} 16$ in normal and ovarian carcinoma tissues, we performed PCR amplification using a $\beta$-tubulin internal standard. ${ }^{13}$ Oligonucleotide primers used for co-amplification of $\mathrm{p} 16$ and $\beta$-tubulin are given in Materials and Methods. Several genes were tested as internal controls, and $\beta$-tubulin was the most satisfactory. Actin was found to be overexpressed in carcinoma by two- to fourfold and was

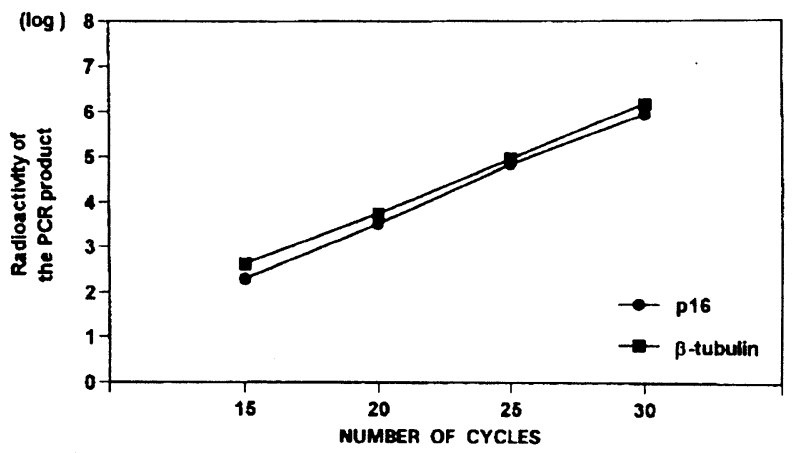

Figure 1. Linearity of the $\beta$-tubulin and the p16 polymerase chain reaction (PCR) products over 30 cycles.

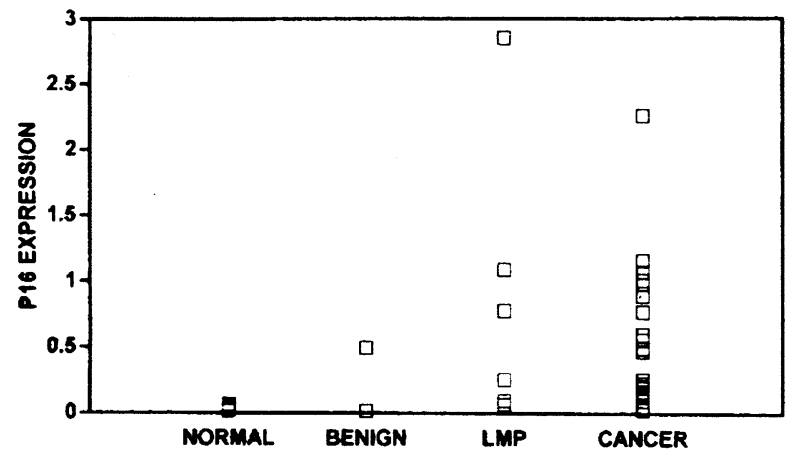

Figure 2. Expression of $p 16$ relative to $\beta$-tubulin (ratio of $p 16 / \beta$ tubulin) in normal ovary, benign ovarian tumor, low malignant potential (LMP) tumor, and ovarian cancer. Expression of p16 is significantly elevated in many ovarian tumor cases.

not used for this reason. Glyceraldehyde 3-phosphate dehydrogenase was consistently expressed, but was so highly expressed relative to most genes that relative expression determinations were difficult for genes of average or low expression. Beta-tubulin was found to be the most consistently expressed in normal and carcinomatous tissues and was not so highly expressed as to compromise the evaluation of comparison genes of low or average expression.

We examined the relative expression of the 16 gene from six normal ovarian tissues, two benign adenomas, six adenomas of low malignant potential, and 24 ovarian carcinomas (Figure 2). The relative expression of $p 16$ to $\beta$-tubulin was elevated in most ovarian tumors ( 28 of 32 or $88 \%$ compared with normal ovaries). Expression of p 16 in most tumors ( 26 of $32,81 \%$ ) was four or more standard deviations above the mean for the nor-

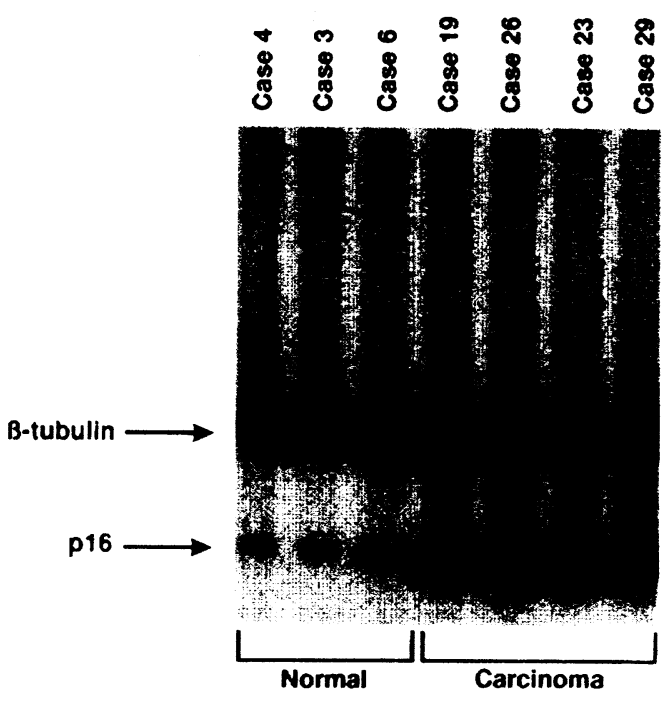

Figure 3. p16 and $\beta$-tubulin $\mathrm{PCK}$ products from normal ovary and ovarian cancer. Case 4 , case 3 , and case 6 are normal ovaries. Case 19 case 26 , case 23, and case 29 are ovarian cancers. Expression of p16 relative to $\beta$-tubulin is higher in cancer samples than in normal ovaries. 
Table 1. p16 Overexpression versus Disease, Stage, and Tumor Type

\begin{tabular}{lcc}
\hline \multicolumn{1}{c}{ Disease } & $\boldsymbol{N}$ & $\begin{array}{c}\mathrm{p}-\mathbf{1 6} \\
\text { Overexpression* }\end{array}$ \\
\hline Normal ovary & 6 & 0 \\
Benign tumor & 2 & $1(50 \%)$ \\
Low malignant potential & 6 & $5(83 \%)$ \\
Carcinoma & 24 & $22(92 \%)$ \\
$\quad$ Stage & & \\
$\quad$ I-II & 4 & $3(75 \%)$ \\
$\quad$ III-IV & 20 & $19(95 \%)$ \\
Type & & \\
$\quad$ Serous & 17 & $15(88 \%)$ \\
$\quad$ Others & 7 & $7(100 \%)$ \\
\hline
\end{tabular}

* Overexpression $=+2 \mathrm{SD}$ or greater over the mean normal values.

+ Including endometrioid, clear-cell, and mucinous.

mal ovary. Figure 3 compares p16 expression in normal ovarian tissue versus ovarian carcinoma. Five of six low malignant potential tumors (83\%) and 22 of 24 carcinomas (92\%) showed overexpression (Table 1). With respect to clinical stage of disease, three of four $(75 \%)$ stage I-II carcinomas and 19 of 20 (95\%) stage III-IV carcinomas showed significant p16 mRNA elevation (Table 1). One of the two benign adenomas examined also exhibited p16 overexpression. Normal levels of $\mathrm{p} 16$ were found in only one adenoma, one mucinous adenoma of low malignant potential, and two serous carcinomas.

\section{p16 Mutations}

To determine whether the overexpression of p16 could be related to mutation resulting in dysfunction of the cell-cycle inhibitor, we sequenced the PCR-amplified products of the p16 gene for all 38 specimens. The p16 gene was amplified using two sets of primers (see Materials and Methods) that extended from the middle of exon 1 (amino acid 40) through the end of exon 3. This area encompasses the known mutations already described for $\mathrm{p} 16$. No mutations were discovered in the six normal specimens. Four sequence alterations were discovered in the 32 tumor specimens (Table 2). A benign tumor (case 8 ) showed a $G$ to $T$ transversion in codon 127 which has previously been described as a polymorphism. ${ }^{11}$ One tumor of low malignant potential (case 9) and one ovarian cancer (case 24) showed the same $G$ to A transition in codon 148 , a known polymorphism. ${ }^{8.10 .11}$ One low malignant potential tumor (case 12) showed a $G$ to A transition in codon 68 This base change, however, does not alter the amino acid sequence of the $\mathrm{p} 16$ protein. Overexpression of $\mathrm{p} 16$ and base alteration data are summarized in Table 3 , indicating an overexpression rate of $88 \%$ ( 28 of 32 ) in ovarian tumors with four cases of base alteration, including three known polymorphisms and one mutation without an amino acid sequence change

\section{Western Blot p16 Expression}

To confirm that p16 mRNA overexpression results in an actual accumulation of the p16 protein, two tumor cases that had demonstrated overexpression of $\mathrm{p} 16 \mathrm{mRNA}$ were examined by comparing them with normal ovarian tissue by Western blot. Both samples showed overexpression of $\mathrm{p} 16$ protein compared with normal ovarian tissue. In Figure 4, tumor p16 protein extracted from case 27 (lane 2 ) is compared with extracts from normal tissue (lane 1) and Hela cell (lane 3), known to overexpress the p16 protein. The second band of higher molecular weight noted in the Western blot (lanes 2-3) has been identified as a cross-reacting protein with the p16 antibody and is found only in tumor extracts associated with p16 overexpression.

\section{Immunohistochemistry}

To confirm that $\mathrm{p} 16$ overexpression was actually occurring in tumor cells and not in the underlying stromal or vascular tissue, we also examined $\mathrm{p} 16$ expression using immunohistochemical staining of paraffin-embedded, formalin-fixed sections of normal ovary and ovarian carcinoma (Table 4). Five normal ovarian tissues, four low malignant potential tumors, and 15 carcinomas were examined using immunohistochemistry. All four of the low malignant potential tumors and 14 of 15 of the carcinomas showed increased staining for p16 (Figure 5C, D). One clear-cell carcinoma had a weak positive staining similar in intensity to that detected in two of the five normal ovarian epithelial specimens (Figure 5A, B). A comparison of p16 expression examined by both quantitative PCR and immunohistochemistry confirms the efficacy of both approaches in demonstrating the overexpression of p16 in both low malignant potential and invasive ovarian carcinomas (Table 5).

\section{DISCUSSION}

It is now evident that the progression of cells through the cell cycle is regulated by positive signals (cyclins and cyclindependent kinases) and negative signals (cyclin-dependent kinase inhibitors such as p21 and p16). ${ }^{2-4}$ Thus, p16 binds to $\mathrm{CDK} 4 / 6$ and inhibits the catalytic activity of cyclinD/

Table 2. Ovarian Tumors With p16 Base* Alterations

\begin{tabular}{|c|c|c|c|c|c|}
\hline $\begin{array}{c}\text { Case } \\
\text { no. }\end{array}$ & Tumor type & Exon & Codon & Base change & Amino acid change \\
\hline 8 & S Cystadenoma & 2 & aa $127^{\dagger}$ & GCA-TCA & Ala-Ser \\
\hline 9 & S Cystadenoma (LMP) & 2 & aal $48^{\ddagger}$ & GCG-ACG & Ala-Thr \\
\hline 12 & M Cystadenoma (LMP) & 2 & aa68 & GCG-GCA & $\mathrm{Ala}-\mathrm{Ala}$ \\
\hline 24 & S Carcinoma & 2 & aal $48^{\ddagger}$ & $G C G-A C G$ & Ala-Thr \\
\hline
\end{tabular}

$s=$ serous; $M=$ mucinous: $L M P=$ low malignant potential.

* Four hase changes in 32 ovarian tumors were observed. Three are known polymorphisms; one base change in codon 68 did not alter the original amino acid.

${ }^{\dagger} \mathrm{G} \rightarrow \mathrm{T}$ transversion in codon 127 has been described as polymorphisn.

${ }^{\ddagger} \mathrm{G} \rightarrow \mathrm{A}$ transition in coden 148 has been described as polymorphism. 
Table 3. Expression and Mutation Analysis of $\mathrm{p} 16$ Genes in Normal Ovaries and Ovarian Tumors

\begin{tabular}{|c|c|c|c|c|c|}
\hline \multirow{2}{*}{$\begin{array}{l}\text { Case } \\
\text { no. }\end{array}$} & \multirow{2}{*}{$\begin{array}{c}\text { Histologic } \\
\text { type }\end{array}$} & \multirow{2}{*}{$\begin{array}{l}\text { Stage/ } \\
\text { grade* }\end{array}$} & \multirow{2}{*}{$\begin{array}{c}\text { Lymph node } \\
\text { metastasis }\end{array}$} & \multicolumn{2}{|c|}{ p16 } \\
\hline & & & & Expression $^{\dagger}$ & Mutation \\
\hline 1 & $\mathrm{~N}$ & & & $\mathrm{~N}$ & WT \\
\hline 2 & $\mathrm{~N}$ & & & $\mathrm{~N}$ & WT \\
\hline 3 & $\mathrm{~N}$ & & & $\mathrm{~N}$ & WT \\
\hline 4 & $\mathrm{~N}$ & & & $\mathrm{~N}$ & WT \\
\hline 5 & $\mathrm{~N}$ & & & $\mathrm{~N}$ & WT \\
\hline 6 & $\mathrm{~N}$ & & & $\mathbf{N}$ & WT \\
\hline 7 & SA (benign) & & & +4 & WT \\
\hline 8 & SA (benign) & & & $\mathrm{N}$ & POL \\
\hline 9 & SA (LMP) & $1 / 1$ & NI & +2 & POL \\
\hline 10) & SA (LMP) & $1 / 1$ & - & +4 & WT \\
\hline 11 & MA (LMP) & $1 / 1$ & - & +4 & WT \\
\hline 12 & MA (LMP) & $1 / 1$ & NI & +4 & MUT \\
\hline 13 & MA (LMP) & $1 / 1$ & NI & +4 & WT \\
\hline 14 & MA (LMP) & $1 / 1$ & NI & $\mathrm{N}$ & WT \\
\hline 15 & SC & $1 / 2$ & - & +2 & W'T \\
\hline 16 & SC & $1 / 3$ & - & +4 & WT \\
\hline 17 & SC: & $2 / 1$ & NI & $\mathrm{N}$ & WT \\
\hline 18 & SC: & $3 / 2$ & + & +4 & WT \\
\hline 19 & SC & $3 / 3$ & NI & +4 & WT \\
\hline 20 & $\mathrm{SC}$ & $3 / 2$ & NI & +4 & WT \\
\hline 21 & $\mathrm{SC}$ & $3 / 2$ & NI & $N$ & WT \\
\hline 22 & $\mathrm{SC}$ & $3 / 3$ & $\mathrm{NI}$ & +4 & WT \\
\hline 23 & SC & $3 / 3$ & $\mathrm{NI}$ & +4 & WT \\
\hline 24 & SC & $3 / 3$ & - & +4 & POL \\
\hline 25 & SC & $3 / 3$ & NI & +4 & WT \\
\hline 26 & $\mathrm{SC}$ & $3 / 1$ & NI & +4 & $W T$ \\
\hline 27 & $\mathrm{SC}$ & $3 / 2$ & NI & +4 & WT \\
\hline 28 & $\mathrm{SC}$ & $3 / 3$ & $\mathrm{Nl}$ & +4 & WT \\
\hline 29 & SC & $3 / 3$ & NI & +4 & WT \\
\hline 30 & SC & $3 / 3$ & $\mathrm{NI}$ & +4 & WT \\
\hline 31 & SC & $3 / 3$ & - & +4 & WT \\
\hline 32 & MC & $1 / 2$ & - & +4 & WT \\
\hline 33 & $\mathrm{MC}$ & $3 / 2$ & $\mathrm{NI}$ & +4 & WT \\
\hline 34 & $M C$ & $3 / 2$ & $\mathrm{NI}$ & +4 & WT \\
\hline 35 & $M C$ & $3 / 1$ & $\mathrm{NI}$ & +4 & WT \\
\hline 36 & EC & $3 / 3$ & $\mathrm{NI}$ & +4 & WT \\
\hline 37 & CC & $3 / 3$ & + & +4 & WT \\
\hline 38 & $\mathrm{CC}$ & $3 / 3$ & + & +4 & WT \\
\hline
\end{tabular}

$\mathrm{N}=$ normal ovary: $\mathrm{W} T \mathrm{~T}=$ wild type; $\mathrm{SA}=$ serous adenoma; $\mathrm{POL}=$ polymorphism; $\mathrm{LMP}=$ low malignant potencial; $\mathrm{VI}=$ not identified: $\mathrm{MA}=$ mucinous adenoma; $\mathrm{MLT}=$ silent mutation; $\mathrm{SC}=$ scrous carcinoma; $\mathrm{MC}=$ mucinous carcinoma; $\mathrm{EC}=$ endometrioid carcinoma: $\mathrm{CC}=$ clear-cell carcinoma.

* International Federation of Gynecology and Obstetrics stage and histologic grade.

$t_{\text {Nomal }}$ range $=$ mean $\left.+2 \mathrm{SD}\right) .2=$ mean $+2 \mathrm{SD}$ to $+4 \mathrm{SD} .+4=$ mean $\left.+4 \mathrm{SI}\right)$ or greater.

CDK4/6 complex, which controls cell passage through the G1 phase of the cell cycle by phosphorylation of the retinoblastoma protein (Figure 6). In this manner, p16 could act as a tumor suppressor gene. Conflicting results have been reported concerning the frequency of p 16 mutations. It has been reported that 16 homozygous deletions were found frequently in cell lines derived from a wide variety of human tumors, including lung, breast, brain, skin, bladder, kidney, and ovary, as well as in leukemia and melanoma. ${ }^{x-9}$ However, it has also been reported that the frequency of intragenic p16 mutations was quite low in primary tumor samples of lung, brain, bladder, kidney, ovary, liver, colon, and head and neck. ${ }^{11-12}$ With respect to ovarian tumors, Kamb et al ${ }^{\varnothing}$ reported p16 deletions in two of seven lesions. However, Okamoto et al ${ }^{12}$ found only one p16 mutation among 18 primary ovarian tumors.

In the present study, the results obtained for $\mathrm{p} 16$ expression in ovarian carcinoma are relatively clear. A very high percent-
1

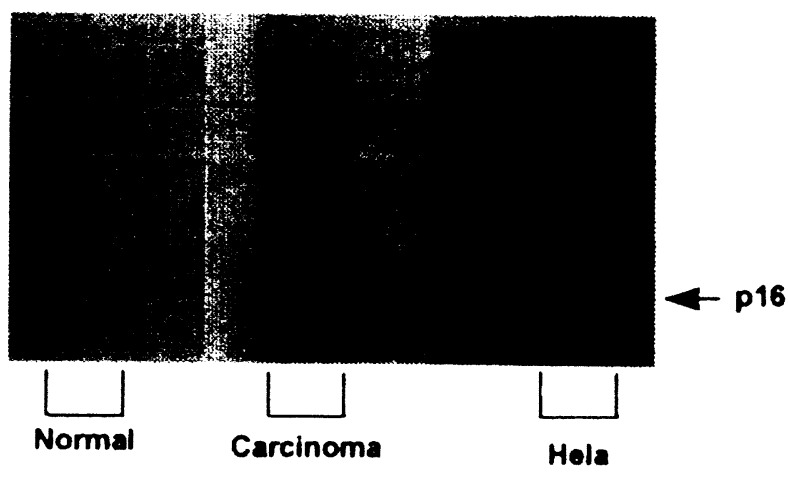

Figure 4. Westem blot analysis of p16 protein. Lane $1=$ normal ovary. Lane 2 = ovarian cancer case 27 , which showed p16 mRNA overexpression. Lane $3=$ Hela cell line as positive control. The 16 protein is strongly positive in the ovarian carcinoma sample and the Hela cell line, but is negative in the normal ovary sample. 
Table 4. Immunohistochemistry: Expression of $\mathrm{p} 16$ Protein in Normal Ovaries and Ovarian Tumors

\begin{tabular}{lcc}
\hline \multicolumn{1}{c}{ Histology } & mRNA* & Protein \\
\hline Normal ovary & $\mathrm{N}$ & - \\
Normal ovary & $\mathrm{N}$ & - \\
Normal ovary & $\mathrm{N}$ & \pm \\
Normal ovary & $\mathrm{N}$ & \pm \\
Normal ovary & $\mathrm{N}$ & - \\
Serous LMP & $2+$ & $2+$ \\
Mucinous LMP & $4+$ & $2+$ \\
Mucinous LMP & $4+$ & $2+$ \\
Mucinous LMP & $\mathrm{N}$ & $2+$ \\
Serous carcinoma & $4+$ & $2+$ \\
Serous carcinoma & $\mathrm{N}$ & $2+$ \\
Serous carcinoma & $\mathrm{N}$ & $2+$ \\
Serous carcinoma & $4+$ & $2+$ \\
Serous carcinoma & $4+$ & $2+$ \\
Serous carcinoma & $4+$ & $2+$ \\
Serous carcinoma & $4+$ & $2+$ \\
Serous carcinoma & $4+$ & $2+$ \\
Serous carcinoma & $4+$ & $2+$ \\
Serous carcinoma & $4+$ & $2+$ \\
Mucinous carcinoma & $4+$ & $2+$ \\
Mucinous carcinoma & $4+$ & $2+$ \\
Mucinous carcinoma & $4+$ & $2+$ \\
Endometrioid carcinoma & $4+$ & \pm+ \\
Clear-cell carcinoma & $4+$ & \\
\hline
\end{tabular}

$\mathrm{N}=$ nomal; LMI' = low malignant potential.

* mRNA expression of pl6 (see Table 3 ).

$t+=$ verv weak positive vaining on the surtace of epithelial cells. $3+=$ strong staining in more than $50 \%$ of tumor cells.
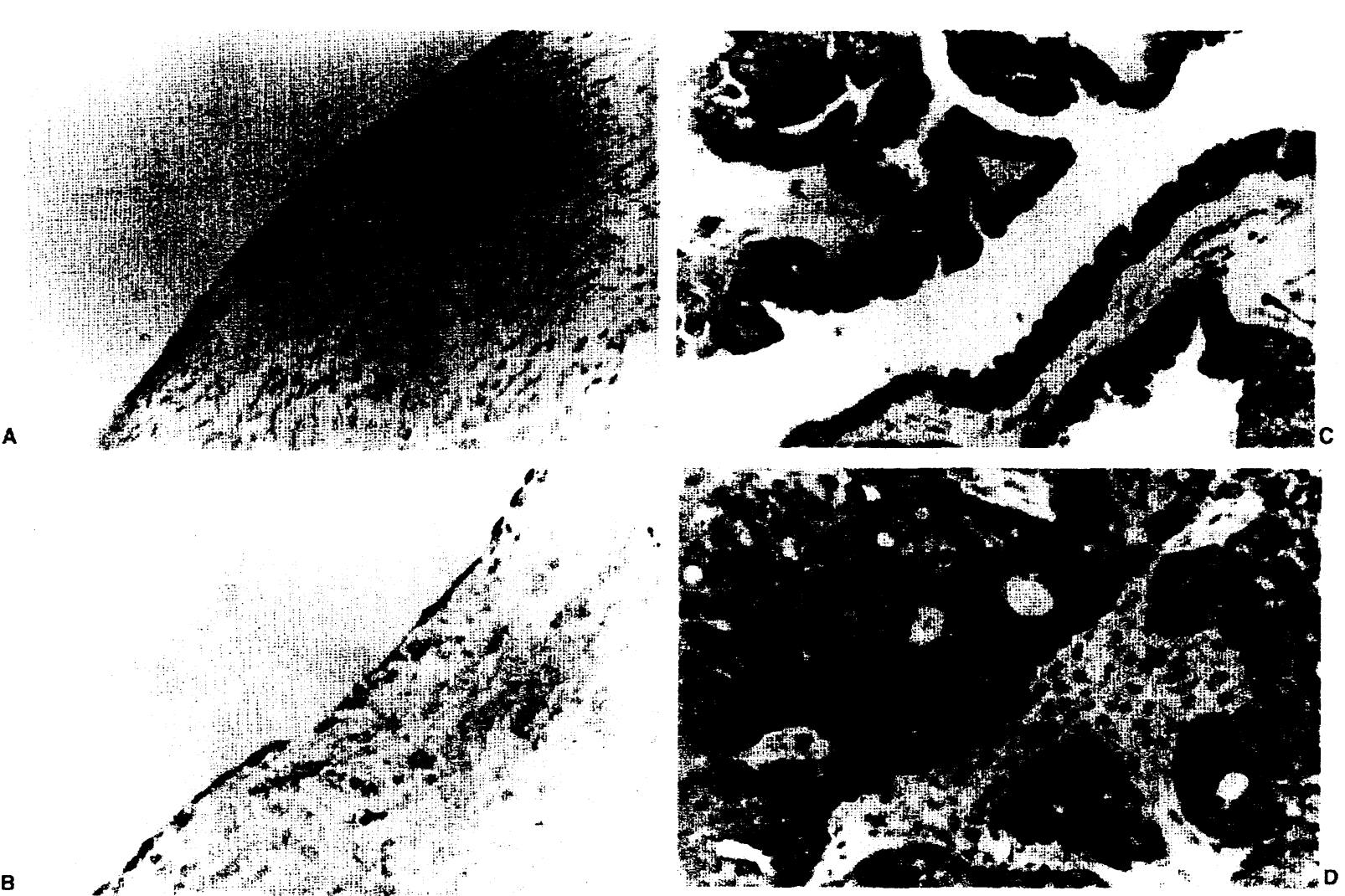

B

Figure 5. Immunohistochemistry. A) p16 is negative on the normal ovarian surface epithelium. B) Very weak pl6 positive staining is observed on the part of the surface epithelium of normal ovary. C,D) plo is strongly positive in the cytoplasm of cancer cells.

Table 5. Comparison of 16 Expression by Quantitative

Polvmerase Chain Reaction and Immunohistochemistry in Normal Ovary and Ovarian Cancer

\begin{tabular}{lccc}
\hline \multicolumn{1}{c}{ Disease } & $N$ & $\begin{array}{c}\text { mRNA } \\
\text { Overexpression }\end{array}$ & $\begin{array}{c}\text { Protein } \\
\text { expression }\end{array}$ \\
\hline Normal & 6 & $0 / 6$ & $0 / 5^{*}$ \\
Benign & 2 & $1 / 2$ & \\
Low malignant potential & 6 & $5 / 6$ & $4 / 4$ \\
Carcinoma & 24 & $22 / 24$ & $14 / 15^{\dagger}$ \\
\hline
\end{tabular}

* Two cases showed weak staining on the surface epithelium.

$t$ One case showed weak staining in less than $31 \%$ of tumor cells.

age (approximately 90\%) of high-stage carcinomas appeared to overexpress the $\mathrm{p} 16$ gene as assessed by quantitative PCR and confirmed in selected cases by both Western blot and immunohistochemistry. These data therefore suggest not only that mRNA is overexpressed, but also that this is translated effectively into a p 16 product that presumably accumulates in the cytoplasm of carcinoma cells. Furthermore, sequencing of the p16 gene from this series of tumors demonstrates that no alteration in amino acids occurred, and therefore the protein product of this overexpressed mRNA gene is a putatively functional wild-type product that presumably has the capacity to bind to CDK4 and CDK6. Such a situation, of course, is paradoxical because these malignant carcinomas are highly proliferative and obviously freely and frequently pass through the cell cycle without regard to the regulatory capacity of this 


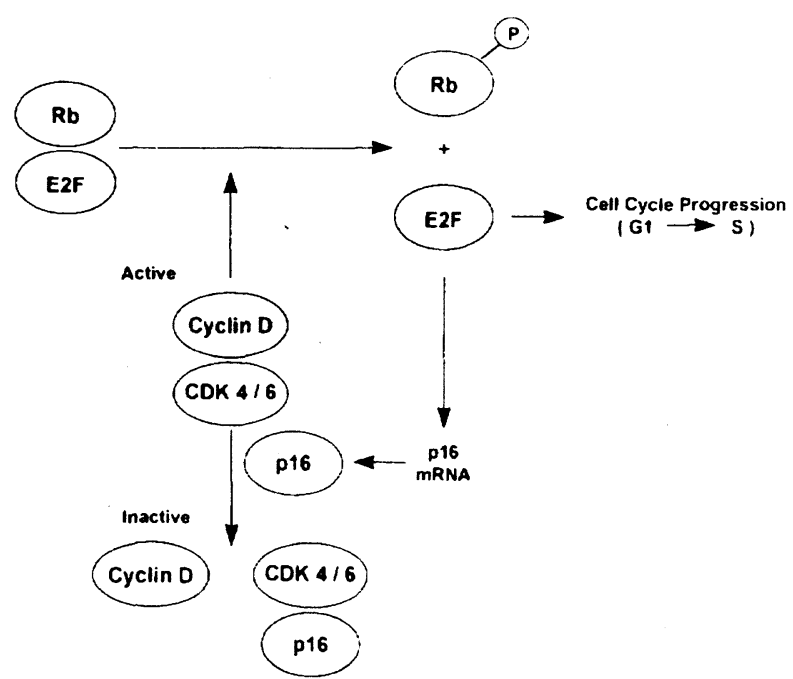

Figure 6. Cyclin $D$ and $C D K 4 / 6$ stinulate cell division by phosphorylating $\mathrm{Rb}$ (retinoblastoma) protein. A transcription factor such as $\mathrm{E} 2 \mathrm{~F}$ is released and activates the transition from $\mathrm{G} 1$ to $S$ phase. $\mathrm{p} 16$ binds to the catalytic subunit $\mathrm{CDK} 4$ or $\mathrm{CDK} 6$ and inactivates the cyclin D-CDK $4 / 6$ complex. E2F released from $\mathrm{Rb}$ may also activate the transcription of 16 .

overexpressed p16 protein. Although the obvious conclusion might have been that $\mathrm{p} 16$ was mutated, this was not the case. As such, the data point to some downstream dysfunction that allows continued cell-cycle progression without regulation. Several potential candidates may be suggested for this downstream dysfunction, which would allow constitutive cell cycling in the face of overexpressed levels of p16 (Figure 6). They are as follows: 1) a defect in the cyclin-dependent kinase that would prevent p16 binding and therefore downregulation; 2) the activation of an alternate pathway to phosphorylate the $\mathrm{Rb}$ protein and therefore bypass $\mathrm{p} 16$ regulation; 3) a defect in the $\mathrm{Rb}$ protein that allows it to be constitutively active and therefore not regulatable; 4) an incapacitated phosphatase that allows continued activity of the $\mathrm{Rb}$ protein due to its hyperphosphorylation and the loss of capacity to be dephosphorylated and reassociated with E2F, 5) a defect in the $\mathrm{Rb}$ or E2F transcription factor that would not allow dimerization of the hypophosphorylated form and therefore inactivation of the complex; 6) an endogenous binding protein that inactivates p16 and prevents it from binding to CDK2 and CDK4; or 7) overexpression of cyclin D and CDK4 and CINK6, which would override and outperform the inhibitory effects of the high levels of $\mathrm{p} 16$ present. It should be pointed out that although the predominant observation was overexpression of p16 in most tumors, there were three tumors that did not overexpress the 16 gene; these suggest the existence of another matrix of genetic insults that may be implicated in ovarian cancer. At present, there are no data to suggest what this combination of insults might be, but it is possible that some small group of the tumors do not include the phenomenon of p16 overexpression.

Although there may be insufficient data to conclude that p16 dysfunction is an early consequence in the transformation process, and may actually precede it, such an indication may be possible. It could be viewed as an early loss of cell-cycle control, which would allow low malignant potential growth or benign growth and therefore could be a contributing factor to the downstream potential for metastatic and pervasive growth. The data indicated overexpression in most low malignant potential tumors and in one of two benign tumors. Clearly, further evaluation and a more extensive study in this area are warranted. Loss of control of the cell cycle at the G1 interface through lack of control of p16 appears to precede the mutations that occur in $\mathrm{p} 53$, resulting in underexpression of $\mathrm{p} 21$ and subsequent loss of control of the cell cycle. More recently, the p15 gene, a close relative of p16, has also been described, although its role in ovarian carcinoma is still unclear. ${ }^{15}$ In addition, hypermethylation of the p 16 gene in CPG islands has been demonstrated as contributing to the reduced expression of this gene, and therefore hypomethylation may be a factor in the overexpression noted here. ${ }^{16}$ Because $p 16$ is overexpressed in most ovarian tumors-both low malignant potential and high-grade disease-there is no obvious correlation between $\mathrm{p} 16$ overexpression and $\mathrm{p} 53$ mutation or $\mathrm{p} 21$ underexpression. Overexpression of p16 is both an earlier event in the development of these ovarian carcinomas and is manifest in a much higher percentage of tumors than is p 53 mutation or p 21 underexpression. To clarify this paradox, we will continue to evaluate the downstream factors already mentioned in this discussion in an attempt to elucidate the relations between a dysfunctional cell-cycle control system and overexpression of p16 in ovarian carcinoma.

\section{REFERENCES}

1. Hartwell LH, Kastan MB. Cell cycle control and cancer. Science 1994;266:1821-8.

2. Hunter T. Braking the cycle. Cell 1993;75:839-41.

3. Peter M, Herskowitz I. Joining the complex: Cyclin-dependent kinase inhibitory proteins and the cell cycle. Cell 1994;79:181-4.

4. Li Y, Nichols MA, Shay JW, Xiong Y. Transcriptional repression of the D-type cyclin-dependent kinase inhibitor p 16 by the retinoblastoma susceptibility gene product $\mathrm{pRb}$. Cancer Res 1994; 54:6078-82.

5. Matsushima H, Ewen ME, Strom DK, et al. Identification and

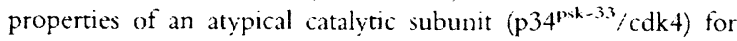
mammalian D type G1 cyclins. Cell 1992;71:323-34.

6. Weinberg RA. The retinoblastoma protein and cell cycle control. Cell 1995;81:323-30.

7. Serrano M, Hannon GJ, Beach D. A new regulatory motif in cell-cycle control causing specific inhibition of cyclin D/CDK4 Nature 1993;366:704-7.

8. Kamb A, Gruis NA, Weaver-Feldhaus J, et al. A cell cycle regulator potentially involved in genesis of many tumor types. Science 1994:264:436-40.

9. Nobori T, Miura K, We DJ, Lois A, Takabayashi K, Carson D. Deletion of the cyclin-dependent kinase-4 inhibitor gene in multiple human cancers. Nature 1994;368: $753-6$.

10. Cairns P, Mao L, Merlo A. et al. Rates of p16 (MTS1) mutations in primary tumors with $9 \mathrm{p}$ loss. Science 1994:265:415-6.

11. Spruck CH III, Gonzalez-Zulueta M, Shibata A, et al. p16 gene in uncultured tumors. Nature 1994;371:183-4. 
12. Okamoto A, Demetrick DJ, Spillare EA, et al. p1 $16^{1 \mathrm{NK} 4}$ mutations and altered expression in human tumors and cell lines. In: The molecular genetics of cancer. Cold Spring Harbor, New York: Cold Spring Harbor Laboratory Press, 1994:49-57.

13. Hall JL, Dudley L, Dobner PR, Lewis SA, Cowan NJ. Identification of two human $\beta$-tubulin isotypes. Mol Cell Biol 1983;3: $854-62$.

14. Noonan KE, Beck C, Holzmayer TA, et al. Quantitative analysis of MDR 1 (multidrug resistance) gene expression in human tu- mors by polymerase chain reaction. Proc Natl Acad Sci USA $1990 ; 87: 7160-4$.

15. Herman JG, Jen J, Merlo A, Baylin SB. Hypermethylationassociated inactivation indicates a tumor suppressor role for p15INK4B. Cancer Res 1996;56:722-7.

16. Herman JG, Merlo A, Mao L, et al. Inactivation of the CDKN2/ p16/MTS1 gene is frequently associated with aberrant DNA methylation in all common human cancers. Cancer Res 1995; $55: 4525-30$. 